Journal of Environmental and Agricultural Studies

ISSN: $2710-140$

DOI: $10.32996 /$ jeas

Journal Homepage: www.al-kindipublisher.com/index.php/jeas

\title{
Coffee Business Development Index Analysis Arabica (Coffea Arabica) in Purba District, Simalungun Regency, North Sumatra Province
}

\author{
Mei Linda Sipayung ${ }^{1} \square$ Theodora MV Nainggolan $^{2}$ and Tiurmaida Nainggolan ${ }^{3}$ \\ ${ }^{1}$ Department of Agriculture, Darma Agung University, Medan, Indonesia \\ 2University of Sisingamaraja XII Tapanuli, Indonesia \\ ${ }^{3}$ Department of Agriculture, Darma Agung University, Medan, Indonesia
}

$\square$ Corresponding Author: Mei, inda Sipayung, E-mail: meilindasipayunguda@gmail.com

\begin{tabular}{ll}
\hline ARTICLE INFORMATION & ABSTRACT \\
\hline
\end{tabular}

Received: 09 September 2021

Accepted: 16 October 2021

Published: 23 October 2021

DOI: $10.32996 /$ jeas.2021.2.2.4

\section{KEYWORDS}

Production, arabica coffee, development index, business, sustainability
This study aims to determine: To determine the development of Arabica Coffee (Coffea arabica) production over the last 5 years, to determine the availability of production factors (land area, seeds, fertilizers, pesticides, equipment, and labor) for the development of Arabica Coffee (Coffea Arabica, for knowing the relationship between the availability of production factors (land area, seeds, fertilizers, pesticides, equipment, and labor) in the previous year to the production of Arabica Coffee (Coffea arabica), and to determine the business sustainability index of Arabica Coffee (Coffea arabica) viewed from the economic, social aspects and the environment in the research area. The research was conducted in Purba District, Simalungun Regency, where the sample size was 25 Arabica coffee farmers. Data analysis used qualitative descriptive analysis, OLS (Ordinary Least Square), and sustainability index. The Arabica coffee production development index from 2015-2019 decreased from the total production of 555.98 tons to 497.51 tons or the index value decreased by 75 The availability of production factors (land area, seeds, fertilizers, pesticides, equipment, and labor) for the Arabica coffee development index in the study area is available with an average value of 21.17. , fertilizers, pesticides, equipment and manpower) the calculated $F$ value $=0.566<\mathrm{F}$ table 6.16 with a sig value of $0.595>0.05$. In partial land area, seeds, fertilizers, pesticides, and labor have an effect on Arabica coffee production. the average (79.27) is categorized as very sustainable.

\section{Introduction}

Coffee is one of the mainstay commodities of plantations that has a significant contribution to the Indonesian economy, namely as a foreign exchange earner, source of income for farmers, producer of industrial raw materials, job creation, and regional development. In Indonesia, the coffee plant was first introduced by the VOC between the years 1696-1699. Initially, coffee cultivation was only research. However, because the results were satisfactory and considered quite profitable as a trading commodity, the VOC spread coffee seeds to various areas so that the population could plant them. Later, plantations were established, and eventually, coffee plants spread to the Lampung area, West Sumatra, North Sumatra, South Sumatra, and other areas in Indonesia. Coffee is an important commodity in the plantation sub-sector because it plays an important role in the national economy as a source of foreign exchange. This can be seen from the export commodities. Indonesian coffee exports occupy the 4 th position in the world. This can be seen in table 1 :

Table 1 Coffee Export Volume in the World in 2016

\begin{tabular}{|l|l|l|}
\hline No & Country & Export Volume (tonnes) \\
\hline 1 & Brazil & $34,500,000$ \\
\hline 2 & Vietnamese & $23,200,000$ \\
\hline 3 & Colombia & $12,800,000$ \\
\hline $\mathbf{4}$ & Indonesia & $\mathbf{7 , 7 9 4 , 0 0 0}$ \\
\hline
\end{tabular}

Copyright: (c) 2021 the Author(s). This article is an open access article distributed under the terms and conditions of the Creative Commons Attribution (CC-BY) 4.0 license (https://creativecommons.org/licenses/by/4.0/). Published by Al-Kindi Centre for Research and Development, London, United Kingdom. 
Source: BPS Directorate General of Plantation Year 2017

The low quality of coffee is very influential on the price of coffee to be exported. The low quality of coffee also affects the ease of penetrating the international market because importing countries usually want quality coffee. To overcome this problem, the government sets policies that emphasize improving the quality (quality) of coffee and limiting the expansion of coffee areas other than Arabica. With this policy, it is expected that the price and quantity of coffee exports will increase.

Table 2. Area (Ha), Production (Tonnes) and Productivity (Tons/Ha) of Arabica Coffee by Province in Indonesia, 2018

\begin{tabular}{|l|l|l|l|l|}
\hline No & province & $\begin{array}{l}\text { Area } \\
(\mathbf{H a})\end{array}$ & $\begin{array}{l}\text { Production } \\
\text { (Tons) }\end{array}$ & $\begin{array}{l}\text { Productivity } \\
\text { (Ton/Ha) }\end{array}$ \\
\hline 1 & Aceh & 99,882 & 4309 & 0.41 \\
\hline $\mathbf{2}$ & North Sumatra & $\mathbf{7 6 , 2 5 7 . 6 4}$ & $\mathbf{6 2 , 6 0 3 . 9 4}$ & $\mathbf{0 . 8 2}$ \\
\hline 3 & West Sumatra & 20,209 & 15.109 & 0.74 \\
\hline 4 & Jambi & 320 & 74 & 0.05 \\
\hline 5 & Bengkulu & 4.024 & 667 & 0.41 \\
\hline 6 & Lampung & 66 & 43 & 0.65 \\
\hline 7 & West Java & 17,218 & 9,420 & 0.54 \\
\hline 8 & Central Java & 6.456 & 2.269 & 0.35 \\
\hline 9 & In Yogyakarta & 50 & 8 & 0.16 \\
\hline 10 & East Java & 14,000 & 5,600 & 0.40 \\
\hline 11 & Bali & 1527 & 4.103 & 0.35 \\
\hline 12 & West Nusa Tenggara & 2.144 & 704 & 0.32 \\
\hline 13 & East Nusa Tenggara & 17,996 & 7.018 & 0.38 \\
\hline 14 & North Sulawesi & 277 & 133 & 0.48 \\
\hline 15 & Central Sulawesi & 78 & 56 & 0.71 \\
\hline 16 & South Sulawesi & 48.158 & 20,712 & 0.43 \\
\hline 17 & West Sulawesi & 6.238 & 401 & 0.06 \\
\hline 18 & Papua & 9.328 & 904 & 0.20 \\
\hline 19 & West Papua & 514 & 134 & 0.26 \\
\hline Indonesia & $\mathbf{3 3 5 , 7 4 3}$ & $\mathbf{1 7 3 . 2 6 8}$ & $\mathbf{0 . 5 2}$ \\
\hline
\end{tabular}

Source: Indonesian Central Statistics Agency (BPS), Statistics Indonesia, the Year 2019.

From Table 2. above, it can be seen that North Sumatra Province is the largest producer of Arabica coffee, which has an area of $76,257.64$ ha and a production of $62,603.94$ tons. Meanwhile, the province with the lowest production value is DI Yogyakarta Province, with a total production of 8 tons and a productivity level of 0.16 tons/ha. The increase in prices, harvested area, and the amount of Arabica coffee production cause the supply of Arabica coffee to also increase. An overview of harvested area, production, and productivity of Arabica coffee in North Sumatra can be seen in Table 3.

Table 3. Area (Ha), Production (Tons) and Productivity (Tons/Ha) of Arabica Coffee by Regency, in North Sumatra Province in 2018

\begin{tabular}{|r|l|l|l|l|}
\hline \multicolumn{1}{|l|}{ No } & County/City & Area $(\mathbf{H a})$ & $\begin{array}{l}\text { Production } \\
\text { (Tons) }\end{array}$ & $\begin{array}{l}\text { Productivity } \\
\text { (Ton/Ha) }\end{array}$ \\
\hline 1. & Christmas Mandaling & $3,230,21$ & $2,154.31$ & 0.67 \\
\hline 2. & South Tapanuli & 4,521 & 840.04 & 0.41 \\
\hline 3. & North Tapanuli & $16,214.82$ & $14,175,87$ & 0.87 \\
\hline 4. & Toba Samosir & $4,614.46$ & $3,946.90$ & 0.85 \\
\hline $\mathbf{5 .}$ & Simalungun & $\mathbf{8 1 6 0 , 8 6}$ & $\mathbf{3 , 5 8 8 . 5 7}$ & $\mathbf{0 . 4 4}$ \\
\hline 6. & Dairi & 12,067 & 9587.36 & 0.79 \\
\hline 7. & Karo & $9,178,44$ & $13,279.74$ & 1.45 \\
\hline 8. & Deli Serdang & 706.35 & 458,60 & 0.93 \\
\hline 9. & Langkat & 73.40 & 71.24 & 0.97 \\
\hline 10. & Humban Hasundutan & 1494.50 & 8067.36 & 0.70 \\
\hline 11. & Mr. Bharat & 951 & 082 & 1.14 \\
\hline 12. & Samosir & 5.045 & $4,151.96$ & 0.82 \\
\hline North Sumatra & $\mathbf{7 6 , 2 5 7 . 6 4}$ & $\mathbf{6 2 , 6 0 3 . 9 4}$ & $\mathbf{0 . 8 2}$ \\
\hline
\end{tabular}

Source: Central Statistics Agency (BPS) North Sumatra, 2019 
Based on table 3. above, it can be seen that Simalungun Regency is a district in North Sumatra Province which is a district with a fairly large Arabica coffee production, namely 3,588.57 tons.

Table 4. Area (Ha), Production (Tonnes), and Productivity (Tons/Ha) of Arabica Coffee by District, in Kabupaten Simalungun, the Year 2018

\begin{tabular}{|l|l|l|l|l|}
\hline NO & districts & Area (Ha) & Production (Tons) & $\begin{array}{l}\text { Productivity } \\
\text { (Ton/Ha) }\end{array}$ \\
\hline 1 & Silimakuta & 632.12 & 434.71 & 0.68 \\
\hline 2 & Silimahuta & 979.76 & 658.06 & 0.67 \\
\hline $\mathbf{3}$ & Ancient & $\mathbf{3 0 6 . 1 0}$ & $\mathbf{8 3 2 . 5 2}$ & $\mathbf{0 . 6 3}$ \\
\hline 4 & Haranggaol Horizon & 55.00 & 43.70 & 0.79 \\
\hline 5 & Dolok Peace & 127.89 & 740.90 & 0.65 \\
\hline 6 & Sidamalik & 480.49 & 252.10 & 0.52 \\
\hline 7 & Sidamalik Pematang & 121.76 & 667.98 & 0.59 \\
\hline 8 & Grisang Sipangan Bolon & 682.32 & 402.50 & 0.58 \\
\hline 9 & Dolok Panribuan & 180.56 & 91.96 & 0.50 \\
\hline 10 & Joriang Hataran & 161.33 & 73.65 & 0.45 \\
\hline 11 & Panei & 229.06 & 114.79 & 0.50 \\
\hline 12 & Panembelan Panei & 47.88 & 26,40 & 0.55 \\
\hline 13 & Raya & 030.84 & 649,40 & 0.62 \\
\hline 14 & Dolok Glare & 581.05 & 354.35 & 0.60 \\
\hline 15 & Kahean glare & 10.53 & 5.50 & 0.52 \\
\hline 16 & Raya Kahean & 18.64 & 10,30 & 0.55 \\
\hline Simalungun & $\mathbf{8 1 6 0 , 8 6}$ & $\mathbf{3 , 5 8 8 . 5 7}$ & $\mathbf{0 . 4 4}$ \\
\hline
\end{tabular}

Source: Central Statistics Agency (BPS) Simalungun Regency, 2019

Table 4. shows that Purba Subdistrict is the central area of Arabica coffee production which is quite large in Simalungun with a total production of 832.52 tons, and a productivity level of 0.63 tons/ha. The production factors that have a significant effect on the income level of Arabica coffee farmers are land area, number of workers, number of plants, use of fertilizers and pesticides, and the use of equipment which have a negative effect on Arabica coffee production levels. The condition and area of land greatly affect the amount of production and use of labor, so as to increase production yields. Another thing that affects an island that is managed well will be different from land that is not managed properly. So as to increase the amount of production. Bhossaq et al. (2012) stated that the implementation of sustainable development is essentially the result of the interaction of various dimensions of sustainability. Three important dimensions that are often used as references are economic, social, and environmental. Purba, Simalungun Regency, North Sumatra Province. The purpose of the study was to determine the development of Arabica coffee (Coffea arabica) production during the last 5 years in Purba District, Simalungun Regency, North Sumatra Province, to determine the availability of production factors (land area, seeds, fertilizers, pesticides, equipment, and labor) to development of Arabica Coffee (Coffea arabica) in Purba District, Simalungun Regency, North Sumatra Province.

\section{Literature review and frameworks}

2.1 Literature review

Technological developments such as the internet and other online media. Researchers make it easier to conduct research to obtain information and data related to the potential development of Arabica coffee farming (Coffea arabica). This opportunity is for researchers to take data or information from both the farming community and data from the government as access to research similar to the development of Arabica coffee (Coffea arabica) farming.

\subsubsection{Agronomic Aspect}

\subsubsection{Climate}

Arabica coffee (Coffea arabica) can be grown at an evaluation between 500-2,000 mdpl, but optimally in areas that have an altitude between 800-500 mdpl, temperature (temperature) between $17-21^{\circ} \mathrm{C}$, and rainfall between 2,000-3,000 mm/year with \pm 3 months dry. The lowest evaluation limit for Arabica coffee is determined by its resistance to leaf rust disease (Rahmat Rukmana, H. 2014). 


\subsubsection{Growing media}

Table 5. Requirements for Soil Chemical Properties for Coffee Plants

\begin{tabular}{|l|l|l|l|l|}
\hline No. & Soil Chemical Properties & Arabica & Robusta & Liberica \\
\hline 1 & Organic matter content or C . content & $\begin{array}{l}>3.5 \% \\
>2 \%\end{array}$ & $\begin{array}{l}>3.5 \% \\
>2 \%\end{array}$ & $\begin{array}{l}>3.5 \% \\
>2 \%\end{array}$ \\
\hline 2. & C/N Ratio & $10-12$ & $10-12$ & $10-12$ \\
\hline 3. & Cation Exchange Capacity (KPK) & $>15 \mathrm{me} / 100 \mathrm{~g} \mathrm{soil}$ & $>15 \mathrm{me} / 100 \mathrm{~g}$ soil & $\begin{array}{l}>15 \mathrm{me} / 100 \mathrm{~g} \\
\text { soil }\end{array}$ \\
\hline 4. & Wet boredom & $>35 \%$ & $>35 \%$ & $>35 \%$ \\
\hline 5. & soil pH & $5.5-6.5$ & $5.5-6.5$ & $4.5,-6.5$ \\
\hline 6. & Nutrient levels of $\mathrm{N}, \mathrm{P}, \mathrm{K}, \mathrm{Ca}$, and Mg & Enough to high & Enough to high & Enough to high \\
\hline
\end{tabular}

Source: Technical Guidelines for Good Agriculture Practices (GAP on Coffee).

\subsubsection{Characteristics of Good Arabica Coffee Plants (Coffea arabica)}

Characteristics of Arabica coffee plants (Coffea arabica)

The structure of the short Arabica coffee plant resembles a shrub with a height of 2-3 meters. Stems stand upright with a rounded shape. Arabica coffee tree has many branches. The color of Arabica coffee leaves is glossy green, like having a wax coating. Old leaves are dark green. The shape of the leaves is elongated or oval with a tapered leaf tip. The base of the leaf is blunt and has a short stalk. Leaf bone structure pinnate. Arabica coffee begins to flower after the rainy season. Flowers grow in the axils of the leaves. Arabica coffee flowers are white and can self-pollinate. There is no difference between male and female flowers. From bud shape to fruit ready for harvest it takes 8-11 months. Arabica coffee fruit shape is round like an egg, with green fruit color then turns bright red when ripe. When the fruit is ripe, it tends to fall off easily. Therefore, it must be harvested immediately. For details, please read how to harvest coffee cherries. Fruits that fall to the ground will experience a decrease in quality, tend to smell bad. Arabica coffee trees have deep tunjang roots. Use these deep roots to support the tree so it does not collapse easily and survives drought conditions. Root growth is determined from the time the tree is removed from the nursery. Trees whose roots do not grow well will interfere with productivity. Use these deep roots to support the tree so it does collapse easily and survive drought conditions. Root growth is determined from the time the tree is removed from the nursery. Trees whose roots do not grow well will interfere with productivity. Use these deep roots to support the tree so it doesn't collapse easily and survives drought conditions. Root growth is determined from the time the tree is removed from the nursery. Trees whose roots do not grow well will interfere with productivity.

The Arabica coffee (Coffea arabica) variety is S 795. This variety has a productivity of $1000-1500 \mathrm{~kg} / \mathrm{ha}$ at a planting density of 1600-2000 trees per hectare. Begins to flower at the age of 15-24 months. Somewhat resistant to leaf rust attack when planted at an altitude of more than 1000 meters above sea level. USDA 762. The productivity of this type of arabica coffee reaches $800-12000$ $\mathrm{kg} / \mathrm{ha}$. It begins to flower at the age of 32-34 months. Somewhat resistant to leaf rust. Andung sari- Productivity around 350 $\mathrm{kg} / \mathrm{ha}$. It begins to flower at the age of 15-24 months. When planted at an altitude of fewer than 900 meters, this variety is susceptible to leaf rust attack but is quite resistant to planting in less fertile areas. Debt Sign. Its productivity reaches $1500 \mathrm{~kg}$ per hectare. The specialty of Arabica coffee varieties is that they can bear fruit continuously following the pattern of rain distribution. The seeds are large, susceptible to powdery mildew and nematodes, but moderately resistant to leaf rust. It is recommended to be planted at an altitude above 1000 meters above sea level.

\subsection{Economic Aspect}

Coffee drinks are not just a distinctively flavored and stimulating drink because they contain caffeine, but this drink also contains several substances that are beneficial to the body, although the levels are not too high. Chemical, vitamin, and mineral levels of coffee before and after rendang can be seen in table 6

Table 6. Composition of Chemicals, Vitamins and Minerals Coffee Before and After Rendang

\begin{tabular}{|l|l|l|}
\hline \multirow{2}{*}{ Composition } & Rate (\%) & Rendang coffee \\
\cline { 2 - 3 } & Rice coffee & 1.15 \\
\hline Water & 11.25 & 1.24 \\
Caffeine & 1.21 & 14.48 \\
Fat & 12.27 & 0.66 \\
Sugar & 8.55 & 10.89 \\
Cellulose & 18.07 & 4.75 \\
Ash & 3.92 & \\
\hline
\end{tabular}




\begin{tabular}{|l|l|l|}
\hline Vitamin B1 & 0.2 & - \\
Vitamin B2 & 0.23 & 0.3 \\
Vitamin B6 & 0.143 & 0.011 \\
Vitamin B12 & 0.00011 & 0.00006 \\
Sodium & 4 & 1.4 \\
Ferrum & 3.7 & 4.7 \\
Fluorine & 0.45 & 0.24 \\
\hline
\end{tabular}

Source: Ir.Sri Najiyati and Ir. Danarti, 2004.

\subsubsection{Arabica Coffee Farmers}

Arabica coffee farmers are people who depend their lives on agricultural land, especially on Arabica coffee farming as their main livelihood which will be from the sale of Arabica coffee production. Broadly speaking, there are three types of farmers, namely landowner farmers, owner farmers who also work on the land, and farm laborers.

\subsubsection{Factors of Production}

1. Land: Production factors in Arabica coffee (Coffea arabica) farming include land. Soil is a function factor in agriculture, including area, fertility, environment, physical condition, and so on (Daniel, 2015). In general Arabic coffee production potential(Coffea arabica) inland units, namely: ha $=10,000 \mathrm{~m} 2$ with a production plant age of up to 5 years. Planting distance: $2 \mathrm{mx} 2 \mathrm{~m}=2,500$ trees/ha, 1 tree $=30$ branches, 1 branch $=10$ internodes, 1 segment $=15$ seeds

2. Seeds and Seeds: source of seeds must come from the parent garden or company that has been appointed with conditions, namely: Age of seedlings: $8-12$ months, Height: 20-40 cm, Minimum number of old leaves: 5-7, Number of primary branches: 1 , Stem diameter: $5-6 \mathrm{~cm}$. Seeds are an important factor of farming production in a plant because seeds are the beginning of the life of the plant. Seedlings are plant seeds that have grown and meet the requirements to be used as material for further planting (Soekartawi, 2012).

3. Fertilizer: Fertilizer is a material that will be given to the soil both organic and non-organic, with the intention of replacing the loss of nutrients from the soil which aims to increase plant production. Coffee fertilization dose per tree:

1. Age 1 year: 50 gr Urea, 40 gr TSP, and 40 gr KCL.

2. Age 2 years: $100 \mathrm{gr}$ Urea, $80 \mathrm{gr}$ TSP, and $80 \mathrm{gr} \mathrm{KCL}$.

3. Age 3 years: $150 \mathrm{gr}$ Urea, $100 \mathrm{gr} \mathrm{TSP}$, and $100 \mathrm{gr} \mathrm{KCL}$.

4. Age 4 years: 200 gr Urea, $100 \mathrm{gr} \mathrm{TSP}$, and $100 \mathrm{gr} \mathrm{KCL}$.

5. Age 5-10 years: 300 grams of Urea, 150 grams of TSP, and 240 grams of KCL.

6. Age 10 years and over: 500 gr Urea, $200 \mathrm{gr} \mathrm{TSP}$, and $320 \mathrm{gr} \mathrm{KCL}$.

Fertilizer is given twice a year, at the beginning and end of the rainy season, half a dose of each. The method of fertilization is to make a circular trench of trees $\pm 10 \mathrm{~cm}$ deep, with a projected distance of tree crowns $( \pm 1 \mathrm{~m})$.

4. Pesticide: Pesticides are substances used to kill or control various types of pests such as mites, nuisance plants, plant diseases caused by pests, bacteria, and viruses.

5. Equipment: Equipment is all kinds of tools that will be used in a farming business. In a farm, the more equipment, the higher the depreciation cost (Soekartawi, 2012).

\subsubsection{Arabica Coffee Farming}

According to Soekartawi (2012), farming is every combination that is composed (organization) of nature, work, and capital that is shown to production in the agricultural field. In accordance with the limitations, in every farming, there is always an element of land or agricultural land that represents nature. There is an element of energy. Work that relies on members of the farmer's family and various types of capital elements. An important aspect in the production process is the availability of resources or raw materials which can also be referred to as factors of production. As in the agricultural economy, the factors of production can be classified into three parts, namely land, labor, and capital. The notion of production factors can be concluded as resources or inputs consisting of land, labor, capital, and skills needed or used in such a way to produce a commodity of economic value. The combination of these resources must show an efficient production process so that it will minimize expenses production costs. According to Hernanto (2011), labor is an important production factor and needs to be taken into account in the production 
process. In farming, the term labor force is known, namely the number of workers involved in farming activities, both from family workers (TKDK) and workers outside the family (TKLK). Agricultural economics is a part of general economics that studies phenomena and problems related to agriculture, both micro and macro. Social agriculture is the study of human relations with the agricultural environment. The study is carried out through a series of social research steps, which is expected to maximize important decisions in the agricultural sector, both traditional agriculture, and modern agricultural systems. The environment can also be applied according to the view of agriculture. With the view that agriculture is a system, then everything that is outside the system and which affects the state of the system is called the agricultural environment.

\subsection{Framework}

Farmers who run Arabica coffee farming require the availability of sufficient production facilities or production factors (inputs) such as land area, seeds, fertilizers, pesticides, equipment, and labor to maintain the smooth production process and to earn high profits, then Arabica coffee farmers must provide sufficient production facilities (inputs) and plan them long before the production process begins. The relationship between Arabica coffee production is called the dependent variable, with production factors such as land area, seeds, fertilizers, pesticides, equipment, and labor that affect the so-called independent variables (independent variables) are formulated in the form of a production function. The production function in question is the Cobb-Douglas regression model using the OLS (Ordinary Least Square) method which is transformed into a linear regression form.

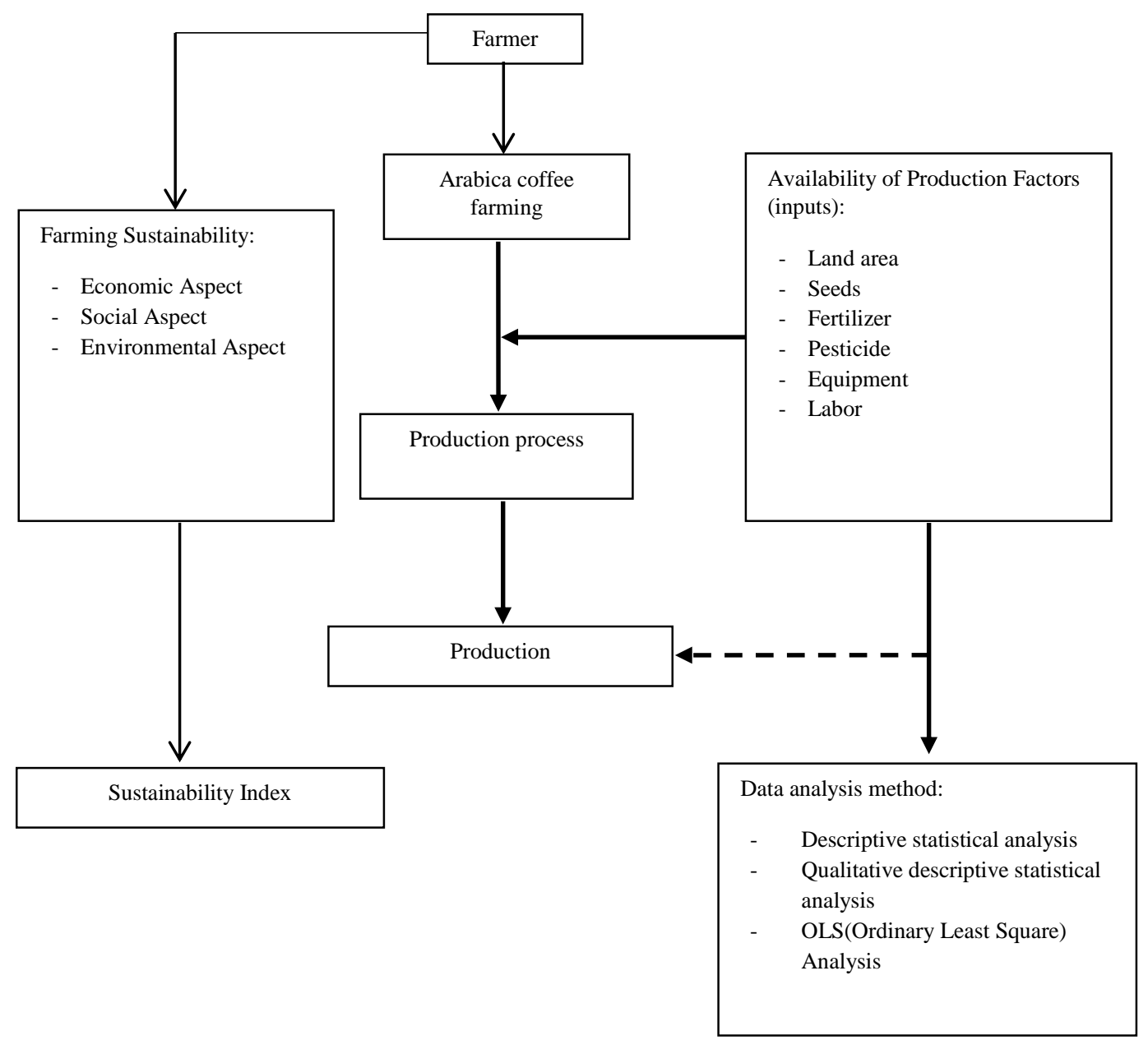

Information :

Relate

- - - $\rightarrow$ Take effect

Figure 2. Schematic Framework of Thinking 


\section{Research Methods}

\subsection{Sampling Method}

Determination of the sample (respondents) is done by Snowball Sampling. Snowball Sampling is a sampling technique for data sources that initially were few in number, but they were not able to provide complete data, so they had to look for other people who could be used as data sources. The number of samples in this study was determined as many as 25 people. (Sugiyono, 2008 ).

\subsection{Data analysis method Descriptive Statistical Analysis}

Descriptive statistical analysis is statistics used to analyze data by describing or describing the data that has been collected as it is without intending to make conclusions that apply to the public or generalizations.

\section{Qualitative Descriptive Analysis}

Qualitative descriptive analysis is an analysis carried out by describing the conditions or circumstances/availability that occurs in the field, in the form of data and information.

\section{OLS (Ordinary Least Square) Analysis}

OLS (Ordinary Least Square) analysis is an econometric method in which there are independent and dependent variables, namely the variables described in a linear equation.

\subsection{Sustainability Index}

The sustainability index is the implementation of sustainable development which is essentially the result of the interaction of various dimensions of sustainability, three important dimensions that are often used as references are economic, social, and environmental.

Multiple linear regression estimator model, mathematically can be written as follows:

$$
\begin{aligned}
& \mathrm{Y} \quad \mathrm{a}+\mathrm{b} 1 \mathrm{X} 1+\mathrm{b} 2 \mathrm{X} 2+\mathrm{b} 3 \mathrm{X} 3+\mathrm{b} 4 \mathrm{X} 4+\mathrm{b} 5 \mathrm{X} 5+\mathrm{b} 6 \mathrm{X} 6+ \\
& \mathrm{Y}=\text { Production arabica coffee in year t (tonnes) } \\
& \mathrm{X} 1=\text { Land area of the previous year (ha) } \\
& \mathrm{X} 2=\text { Seeds of the previous year (tons) } \\
& \mathrm{X} 3=\text { Fertilizer of the previous year (tons) } \\
& \mathrm{X} 4=\text { Pesticides of the previous year (liters) } \\
& \mathrm{X} 5=\text { Previous year's equipment (units) } \\
& \mathrm{X} 6=\text { previous year's workforce (KK) } \\
& \mathrm{X} \quad=\text { Intercept coefficient }
\end{aligned}
$$

b1, b2, b3, b4, b5, and b6, = Regression coefficient (search parameter)

$$
=0,05 \text { (Sugiyono, 2013). }
$$

To find out whether the area of land in the previous year (X1), seeds in the previous year (X2), fertilizer in the previous year (X3), pesticides in the previous year (X4), equipment in the previous year (X5) and labor in the previous year (X6), simultaneously has a significant or no effect on Arabica coffee production in year $t(Y)$, then the $F$ test is used with the following formula:

$$
\mathrm{F}=\frac{R^{2}(\mathrm{n}-\mathrm{k}-1)}{\mathrm{k}\left(1-R^{2}\right)}
$$

Information :

$\mathrm{R}=$ Multiple correlation coefficient

$k=$ Number of independent coefficients

$\mathrm{n}=$ Number of data.

To find out if the area of land in the previous year (X1), seeds in the previous year (X2), fertilizer in the previous year (X3), pesticides in the previous year (X4), equipment in the previous year (X5), and labor in the previous year (X6), partially significant effect or not to production arabica coffee in year $t(Y)$ then the -t-test is used with the following formula:

$$
\begin{aligned}
& t=r \frac{\sqrt{n-2}}{\sqrt{1-r^{2}}} \\
& \text { Information }: \\
& t=t \text { count } \\
& r=\text { Correlation coefficient }
\end{aligned}
$$


$\mathrm{n}=$ number of data (Nachrowi and Usman, 2005)

The Sustainability Index formula is as follows:

$$
\text { Sustainability Index }=\frac{\text { skor yang diperoleh }}{\text { skor maksimum }} \times 100 \%
$$

Information :

Maximum Score $=$ The highest score of the Likert scale $\mathrm{x}$ number of respondents

To determine the indicator value of respondents' answers, the Likert Scale is used as follows:

For answers that do not agree (TS) are given a score of

2. For doubtful answers (R) given a score of: 2

3. For the answer agree $(\mathrm{S})$ given a score $: 3$

4. For answers strongly agree (SS) given a score: 4

The sustainability index is classified into four categories of sustainability status as follows (Thamrin et 2007):

1. 0-25\%: Unsustainable (Bad)

2. 25.01-50.00\%: Less Sustainable (Less)

3. $50.01-75.00 \%$ : Sufficiently Sustainable ( Enough)

4. 75.01-100\%: Highly Sustainable (Good)

\section{Results and Discussion}

4. Results and Discussion

\subsection{Arabica Coffee Production Development}

In the structure of agricultural production by type of sub-sector in 2018 in Purba District, the plantation sub-sector is one of the largest contributors to the community's economy in Purba District, Simalungun Regency. The development of plantation crop production in Purba District (Table 5) with a total land area of1413.2 ha and produce a production of 881.27 tons. The following is the harvested area and production of plantation crops by plant type in Purba District in 2018.

Table 7 Harvested Area and Plantation Crop Production by Plant Type in Purba District in 2018

\begin{tabular}{|l|l|l|}
\hline Plant Type & Production (Tons) & Land Area (Ha) \\
\hline Arabica Coffee & 832.52 & 306.10 \\
\hline Chocolate & 2.40 & 40,30 \\
\hline Clove & 6.82 & 34.00 \\
\hline Sweet Skin & 34.90 & 21.30 \\
\hline Aren & 4.63 & 11.50 \\
\hline Total & $\mathbf{8 8 1 . 2 7}$ & $\mathbf{1 4 1 3 , 2}$ \\
\hline
\end{tabular}

Source: Purba District BPS 2017

Based on table 7. Arabica coffee is a superior crop with a production of 832.51 tons from a land area of 306.10 . While other types of plantation crops are under the production of arabica coffee such as cinnamon with a production of 34.90 tons from a land area of 21.30 , clove plants with a production of 6.82 tons from a land area of 34.00 , sugar palm plants with a production of 4.63 tons from an area of 11.50 land area and the last order are cocoa with a production of 2.40 tons from a land area of 40.30 . To find out the development of Arabica coffee production in the research area, it can be seen in the following graph: 


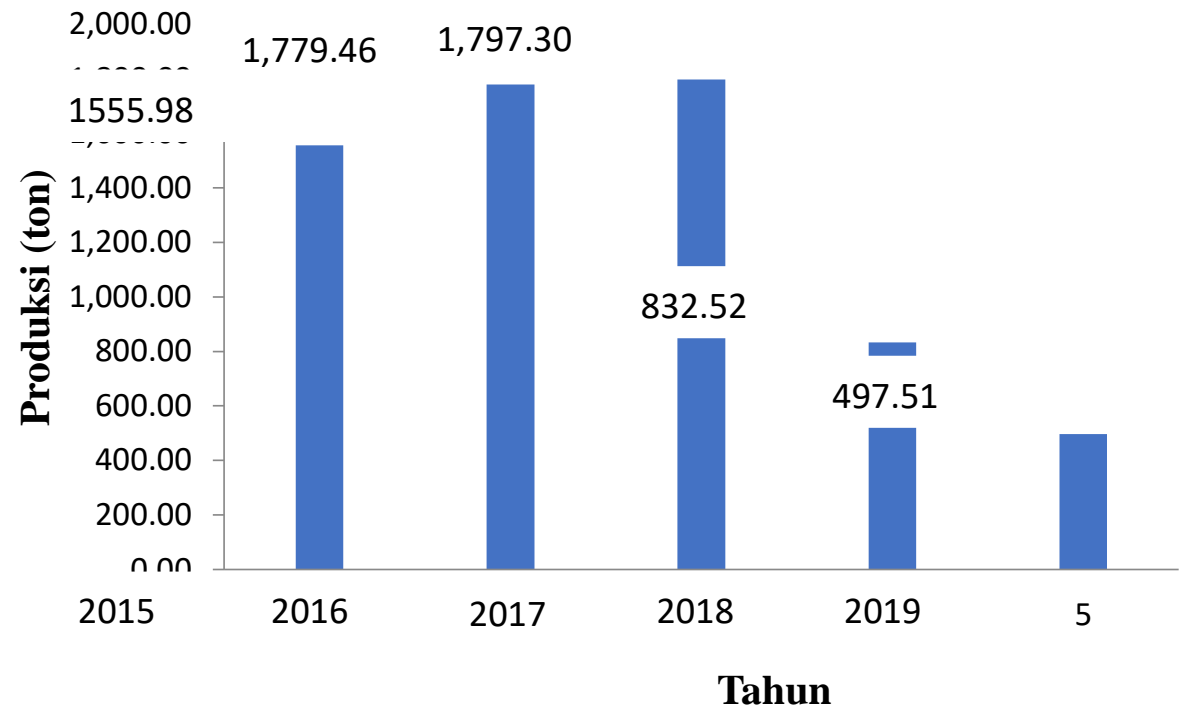

Figure 5. Graph of Arabica Coffee Production Development in 2015-2019

Based on the graph above, it shows that the development of Arabica coffee production in 2015-2019 fluctuated Arabica coffee production. Arabica coffee production in 2015 was 555.98 tons and increased in 2016 and 2017 with a total production of 779.46 tons and797, 30 tons, where the large development of Arabica coffee production from 2015-2017 was 241.32 tons. However, Arabica coffee production from 2017 to 2018 to 2019 again declined by 964.78 tons and 335.01 tons, respectively. The amount of Arabica coffee production in the study area each year fluctuates up and down. This fluctuation occurs due to the addition and reduction of land area, the changing selling price of farmers, and weather factors.

Based on the explanation above, it can be concluded that the hypothesis which states that there is a development of Arabica coffee production in the research area is not accepted because arabica coffee production in 2015-2019 decreased from 555.98 tons to 497.51 tons or a declining index of 75 .

\subsection{Availability of Production Facilities}

The following is level of availability made by respondents can be seen in the following table:

Table 8 Availability of Production Factors in Purba. District

\begin{tabular}{|c|l|l|l|}
\hline No & Variable & Total Score & Category \\
\hline 1. & Land Availability & 25 & Enough Available \\
\hline 2. & Seed Availability & 19 & Enough Available \\
\hline 3. & Fertilizer Availability & 19 & Enough Available \\
\hline 4. & Pesticide Availability & 18 & Enough Available \\
\hline 5. & Equipment Availability & 24 & Enough Available \\
\hline 6. & Labor Availability & 22 & Enough Available \\
\hline
\end{tabular}

Source: Data processed (2020)

Land Availability: Availability of land in the study area is classified as moderately available with a total score of the level of availability of fertilizer is 25 .

Seed Availability: The level of availability of seeds according to respondents' answers is classified in the category of moderately available with a total score of 19 .

Fertilizer Availability: Availability of fertilizer in the research area is categorized as moderately available with a total score of 19.

Pesticide Availability: Availability of pesticides in the study area is categorized as moderately available with a total score of 18. 
Equipment Availability: Availability of equipment in the research area is categorized as moderately available with a total score of 24 fertilizer availability levels.

Labor Availability: Availability of labor in the research area is classified as moderately available with a total score of 22

The availability of production factors above shows that the total score of the six production factors, namely land area, seeds, fertilizers, pesticides, equipment, labor, it can be concluded that the hypothesis stating the availability of production factors in the study area is available is accepted because the criteria for withdrawing the availability of factors production, that is, if the total score of the sample farmers is $>12$, then it is categorized as available and vice versa if the total score of the sample farmers is $<12$, then it is categorized as unavailable.

\subsubsection{The Relationship of Availability of Production Factors in the Previous Year}

The results of the regression analysis of the Cobb-Douglas production function are presented in Table 9 below:

\section{Table 9 Regression Test Results Relation of Availability of Production Factors in the Previous Year to Arabica Coffee} Production

\begin{tabular}{|c|c|c|c|c|c|c|}
\hline \multicolumn{2}{|c|}{ Model } & \multicolumn{2}{|c|}{ Unstandardized Coefficients } & \multirow{2}{*}{$\begin{array}{l}\text { Standardized } \\
\text { Coefficients } \\
\text { Beta } \\
\end{array}$} & \multirow[t]{2}{*}{$\mathrm{t}$} & \multirow[t]{2}{*}{ Sig. } \\
\hline & & $\mathrm{B}$ & Std. Error & & & \\
\hline \multirow{7}{*}{1} & (Constant) & 546010,560 & 523843.329 & & 042 & .337 \\
\hline & Land area & 0.275 & 3.010 & .035 & 5.091 & .430 \\
\hline & Seeds & 17,186 & 188.126 & .035 & 3.051 & .630 \\
\hline & Fertilizer & 10,912 & 119,921 & .034 & 2,041 & .330 \\
\hline & Pesticide & 0.099 & -121 & .437 & 6.320 & .444 \\
\hline & Equipment & 5.486 & 60,212 & .034 & 091 & .930 \\
\hline & Labor & -52102 & 49579 & -.565 & -060 & .330 \\
\hline
\end{tabular}

a. Dependent Variable: Production

Source: Data processed (2020)

Constant $=546010,560$
$\begin{array}{ll}\text { R2 } & =0,954 \\ \text { t table } & =2.015 \\ \text { F table } & =6.16\end{array}$

In this section, the coefficient values $\mathrm{a}, \mathrm{b} 1, \mathrm{~b} 2, \mathrm{~b} 3, \mathrm{~b} 4, \mathrm{~b} 5$ and b6t are calculated and significant. From the table can be obtained the equation:

$Y=546010,560+0.275+17,186+10,912+0.099+5.486-52102$

$\mathbf{R}_{\mathbf{2}}$. test

The Coefficient of Determination (R2) is a coefficient used to see how much the independent variable (land area, seeds, fertilizers, pesticides, equipment, and labor) can explain the dependent variable (production of arabica coffee).

Table 10. Recapitulation of the Coefficient of Determination Test Results (R2)

\begin{tabular}{|l|l|l|l|l|}
\hline \multicolumn{4}{|l|}{ Model Summary } \\
\hline Model & R & R Square & Adjusted R Square & Std. error of the Estimate \\
\hline 1 & $.976 \mathrm{a}$ & .954 & -.122 & 67880712 \\
\hline \multicolumn{4}{|l}{ a. Predictors: (Constant), Labor_Employment, Area_Land, Pesticide, Seedling, } \\
\hline
\end{tabular}

Source: Data processed from Appendix 5

Based on table 10 above, it is known that the resulting Correlation (R) value is 0.976 . Thus, it can be concluded that there is a close relationship between the variables of land area, seeds, fertilizers, pesticides, equipment, and labor as a whole, giving an effect (X) on the Arabica coffee production variable $(Y)$ because the correlation value of 0.976 is close to the number. 


\section{Simultaneous Test (F Test)}

The $\mathrm{F}$ test is used to determine whether the independent variables together have a significant effect on the dependent variable, which can be seen in the following table:

Table 11. Results, Simultaneous Regression Coefficient Test (Test F)

\begin{tabular}{|l|l|l|l|l|l|l|}
\hline \multicolumn{7}{|l|}{ ANOVA } \\
\hline Model & Sum of Squares & df & Mean Square & F & Sig. \\
\hline \multirow{3}{*}{1} & Regression & 5217062585.334 & 2 & 2608531292.667 & 0.566 & $0.595 b$ \\
\cline { 2 - 7 } & Residual & 27647038939.147 & 4 & 4607839823191 & & \\
\cline { 2 - 6 } & Total & 32864101524.480 & 10 & & & \\
\hline
\end{tabular}

\section{Source: Data processed from Appendix 5}

Based on the analysis of the $F$ test, it was found that the calculated $F$ value $=0.566<F$ table $=3.48$ with a sig value of $0.595>$ 0.05 , meaning that the availability of production factors simultaneously significantly affected the production of Arabica coffee in the research area. Value 0.275 is the coefficient of land availability $(X 1)$ which indicates that if the other independent variables have a fixed value and the availability of land has increased by 1 unit, it will increase Arabica coffee production by $0.275 \mathrm{~kg}$. The sign of a positive coefficient for land availability means that the influence of land availability on Arabica coffee production in Purba District is positive, where the greater the availability of land area, the Arabica coffee production in the study area will increase and vice versa. The value of 17,186 is the coefficient of seed availability (X2) which indicates that if the other independent variables have a fixed value and the availability of seeds has increased by 1 unit. It will increase the production of Arabica coffee by $17,186 \mathrm{~kg}$. The sign of a positive coefficient for seed availability means that the effect of seed availability on Arabica coffee production in Purba District is positive, where the higher the availability of seeds, the Arabica coffee production in the study area will increase and vice versa. The value of 10,912 is the coefficient of fertilizer availability (X3) which shows that if the other independent variables have a fixed value and the availability of fertilizer has increased by 1 unit. It will increase the production of Arabica coffee by 10,912 $\mathrm{kg}$. The positive coefficient sign for fertilizer availability means that the effect of fertilizer availability on Arabica coffee production in Purba District is positive, where the higher the availability of fertilizer, the Arabica coffee production in the study area will increase and vice versa. Value 0.099 is the coefficient of pesticide availability (X4) which indicates that if the other independent variables remain constant and the availability of pesticides increases by 1 unit, it will increase the production of arabica coffee by $0.099 \mathrm{~kg}$. The positive coefficient sign for the availability of pesticides means that the influence of the availability of pesticides on the production of arabica coffee in Purba District is positive, where the increasing availability of pesticides, the production of arabica coffee in the study area will increase, and vice versa. The value of 5.486 is the coefficient of equipment availability (X5) which shows that if the other independent variables have a fixed value and the availability of equipment has increased by 1 unit. It will increase the production of Arabica coffee by $5,486 \mathrm{~kg}$.

\section{Partial Test (t-Test)}

The t-test is used to determine whether the independent variable partially affects the dependent variable, which can be seen in the following table:

Table 12 Partial Regression Coefficient Test Results (t-test)

\begin{tabular}{|l|l|l|l|}
\hline Variable & T count & Sign & T table \\
\hline Land area & 5.091 & $>$ & 2,353 \\
\hline Seeds & 3.051 & $>$ & 2,353 \\
\hline Fertilizer & 3.041 & $>$ & 2,353 \\
\hline Pesticide & 6,320 & $>$ & 2,353 \\
\hline Equipment & 1.091 & $<$ & 2,353 \\
\hline Labor & -1.060 & $>$ & $-2,353$ \\
\hline
\end{tabular}

Source: Data processed from Appendix 5

1. Land Area

Partially the availability of land affects the production of Arabica coffee. This can be seen from the value of $t$ count $>t$ table (5.091> 2.353) then $\mathrm{H} 1$ is accepted, meaning that partially the land availability variable ( $\mathrm{X} 1)$ has an effect on Arabica coffee production ( $\mathrm{Y}$ ). 


\section{Seeds}

Based on table 5.6, it can be seen that partially the availability of seeds has an effect on Arabica coffee production. It can be seen from the value of $\mathrm{t}$ count $>\mathrm{t}$ table $(3.051<2,353)$ then $\mathrm{H} 1$ is accepted, meaning that the variable availability of seeds $(\mathrm{X} 2)$ has an effect on Arabica coffee production (Y).

\section{Fertilizer}

Based on table 5.6, it can be seen that partially the availability of fertilizer has an effect on Arabica coffee production. It can be seen from the value of $\mathrm{t}$ count $>\mathrm{t}$ table $(3.041>2,353)$, then $\mathrm{H} 1$ is accepted, meaning that the variable availability of fertilizer $(\mathrm{X} 3)$ has an effect on Arabica coffee production (Y).

\section{Pesticides}

Based on table 5.6, it can be seen that partially the availability of pesticides has an effect on Arabica coffee production. It can be seen from the value of $\mathrm{t}$ count $>\mathrm{t}$ table $(6,320>2,353)$ then $\mathrm{H} 1$ is accepted, meaning that the pesticide availability variable $(\mathrm{X} 4)$ has an effect on Arabica coffee production (Y).

\section{Equipment}

Based on table 5.6, it can be seen that partially the availability of equipment has no effect on Arabica coffee production. It can be seen from the value of $\mathrm{t}$ count $<\mathrm{t}$ table $(1.091<2,353)$ then $\mathrm{H} 0$ is accepted, which means that the variable availability of equipment (X5) has no effect on Arabica coffee production (Y).

\section{Labor}

Based on table 5.6, it can be seen that partially the availability of labor affects the production of Arabica coffee. It can be seen from the value of -t count $>-t$ table $(-1.060>-2,353)$ then $\mathrm{H} 1$ is accepted, which means that the variable availability of labor $(X 6)$ has an effect on Arabica coffee production (Y).

\subsection{Arabica Coffee Farming Sustainability Index}

\subsubsection{Economic Aspect Sustainability Index in Arabica Coffee Farming}

The results of the analysis of the sustainability index of the economic aspect of Arabica coffee farming can be seen in Table 13 below:

Table 13 Economic Aspect Sustainability Index in Arabica Coffee Farming

\begin{tabular}{|l|l|l|}
\hline No & Indicator & Index \\
\hline 1 & Arabica coffee farming is profitable & 76 \\
\hline 2 & Using quality seed input & 75 \\
\hline 3 & Availability of supporting production facilities and infrastructure & 81 \\
\hline 4 & Actively market the products & 75 \\
\hline 5 & Actively seeking market information & 78 \\
\hline
\end{tabular}

Source: Data processed (2020)

The five indicators there are three indicators that fall into the category of highly sustainable indicators, namely index values (76, 81 , and 78). Indicators of the availability of supporting production facilities and infrastructure, indicators of actively seeking market information, and indicators of profitable Arabica coffee farming are indicators that have a relationship closely related to efforts to generate high income from Arabica coffee production activities carried out in the research area. The sustainability values for the three indicators are already good. Meanwhile, the indicators of using quality seed inputs, and indicators of actively marketing their products are categorized into moderately sustainable indicators with indicator index values, namely (75),

\subsubsection{Social Aspect Sustainability Index in Arabica Coffee Farming}

The results of the analysis of the sustainability index of social aspects in Arabica coffee farming can be seen in Table 14 below:

Table 14 Social Aspect Sustainability Index in Arabica Coffee Farming

\begin{tabular}{|l|l|l|}
\hline No & Indicator & Index \\
\hline 1 & Available labor for Arabica coffee farming & 81 \\
\hline 2 & Education determines the success of Arabica coffee farming & 77 \\
\hline 3 & Active in farmer groups & 83 \\
\hline 4 & Farmers' institutions are very helpful & 83 \\
\hline 5 & Easy access to counseling & 85 \\
\hline
\end{tabular}

Source: Data processed (2020) 
From Table 14 above, it can be explained that the five indicators are categorized as highly sustainable with index values $(85,83$, 83,81 , and 77 ). Ease of access to extension and farmer institutions is another factor outside of the farmers that are important to support the success and ensure the sustainability of Arabica coffee farming. The existence of extension workers and farmer institutions will provide solutions to problems, especially related to technical cultivation problems faced by farmers such as the use of production factors to maximize production. Indicators of the availability of labor for Arabica coffee farming, education indicators determining the success of Arabica coffee farming, and indicators of being active in farmer groups are one way to strengthen the skills and abilities of Arabica coffee farmers.

\subsubsection{Environmental Aspect Sustainability Index in Arabica Coffee Farming}

The results of the analysis of the sustainability index of environmental aspects in Arabica coffee farming can be seen in the following table:

Table 15. Environmental Aspects of Sustainability Index in Arabica Coffee Farming

\begin{tabular}{|l|l|l|}
\hline No & Indicator & Index \\
\hline 1 & Assessing the suitability of Arabica coffee farming locations & 77 \\
\hline 2 & Using the appropriate Arabica coffee farming model and construction & 77 \\
\hline 3 & $\begin{array}{l}\text { Looking for information on agricultural products processing } \\
\text { technology }\end{array}$ & 86 \\
\hline 4 & $\begin{array}{l}\text { Use doses of fertilizers and pesticides according to the needs of } \\
\text { Arabica coffee plants }\end{array}$ & 78 \\
\hline 5 & Prevent and overcome the emergence of pests and diseases & 77 \\
\hline
\end{tabular}

Source: Data processed (2020)

Based on Table 15 above can be explained that the five indicators are categorized as highly sustainable with index values $(86,78$, 77, 77, and 77). The indicator of seeking information on agricultural products processing technology is a superior indicator of Arabica coffee farming in the research area. These indicators can be used as a reference for farmers' strategies in processing maximum production results. Maximum production is not only focused on production that increases every year, but also on getting added value so that farmers' income is increasing. In supporting the production of Arabica coffee in the research area, it is inseparable from the indicators of the use of fertilizers and pesticides doses according to the needs of the Arabica coffee plant, and indicators of preventing and overcoming the emergence of pests and diseases.

\subsection{Combined Index of Arabica Coffee Farming Sustainability on Economic, Social and Aspects Environment}

The combined value of the sustainability index for economic, social, and environmental aspects can be seen in Table 14 below:

Table 14 Combined Index of Economic, Social and Environmental Aspects

\begin{tabular}{|l|l|l|l|}
\hline No & Aspect & $\begin{array}{l}\text { Average Sustainability Index } \\
\text { Score }\end{array}$ & Category \\
\hline 1 & Economy & 77.00 & Very Sustainability \\
\hline 2 & Social & 81.80 & Very Sustainability \\
\hline 3 & Environment & 79.00 & Very Sustainability \\
\hline Combined & $\mathbf{7 9 . 2 7}$ & Very Sustainability \\
\hline
\end{tabular}

Source: Processed Data (2020)

Based on Table 14, it is known that the average value of the sustainability index is on the economic (77.00), social (81.80), and environmental (79.00) aspects. The composite index has an average value (79.27) which is categorized as very sustainable. So it can be concluded that the hypothesis that there is an index of Arabica coffee farming sustainability seen from the economic, social, and environmental aspects is "accepted".

\section{Conclusion}

Development of arabica coffee production over the last 5 years decreased in 2015-2017 in the research area. The availability of production factors (land area, seeds, fertilizers, pesticides, equipment, and labor) for the development of Arabica coffee in the research area is available. The results of multiple linear regression analysis showed that the availability of production factors (land area, seeds, fertilizers, pesticides, equipment, and labor) simultaneously (simultaneously) had a significant effect on Arabica coffee production in the previous year. Economic, social, and environmental in the research area. It is necessary to maintain the value of the sustainability index of the economic, social, and environmental aspects by applying 15 indicators so that production, especially 
Arabica coffee, continues to be sustainable. The availability of production factors affects the increase in Arabica coffee production in Purba District significantly,

\section{References}

[1] Central Bureau of Statistics, Directorate General of Plantation. (2017). "The Volume of Coffee Exports in the World in 2016".

[2] Indonesian Central Bureau of Statistics (BPS), Statistics Indonesia, ((2019), "Area Area (Ha), Production (Tonnes) and Productivity (Tons/Ha) of Arabica Coffee by Province in Indonesia, the Year 2018"

[3] Central Bureau of Statistics (BPS) North Sumatra, (2019), "Area (Ha), Production (Tons) and Productivity (Tons/Ha) of Arabica Coffee by District, in North Sumatra Province, 2018".

[4] Central Statistics Agency (BPS) Simalungun Regency, (2019), "Area (Ha), Production (Tonnes), and Productivity (Tonnes/Ha) of Arabica Coffee by District, in Simalungun Regency, 2018".

[5] Central Statistics Agency (BPS) Purba District, (2019) 2011-2020, "Area Area (Ha), Production (Tonnes), and Productivity (Tons/Ha) of Arabica Coffee, Purba District in 2019 figures".

[6] Daniel, M. (2015). Introduction to Agricultural Economics. Jakarta: PT. Earth Literature

[7] Hernanto, F. (2016) Agricultural Science. Self-Help Spreader.

[8] Muljana, W. (2018). Cultivating Coffee. Various Science CV.

[9] Nachrowi M and Usman K. (2005) The Wealth of Nations. Jakarta: Raja Grafindo Persada.

[10] Najiyati, S. and Danarti W. (2004) Cultivated Coffee and Post-Harvest Handling. Self-Help Spreader.

[11] Nazir L. (2011) Research Methods. Indonesian Ghalia

[12] Rahmat R, H., (2014) Untung Selangit from Coffee Agribusiness. Yogyakarta.

[13] Soekarno M. (2012). Agricultural Science. The publisher the University of Indonesia.Jarakta.

[14] Sugiyono M. (2013). Quantitative and Qualitative Research Methods and R \& D. Bandung: Alfabeta.

[15] Independent Farmer Work Team. (2018). Secrets of Coffee Cultivation Success. Nuansa Aulia's CV. 